PREPARED FOR THE U.S. DEPARTMENT OF ENERGY, UNDER CONTRACT DE-AC02-76CH03073

PPPL-3714

PPPL-3714

UC-70

Calculations of Neutral Beam Ion Confinement for the National Spherical Torus Experiment

by

M.H. Redi, D.S. Darrow, J. Egedal, S.M. Kaye, and R.B. White

June 2002

N/M|

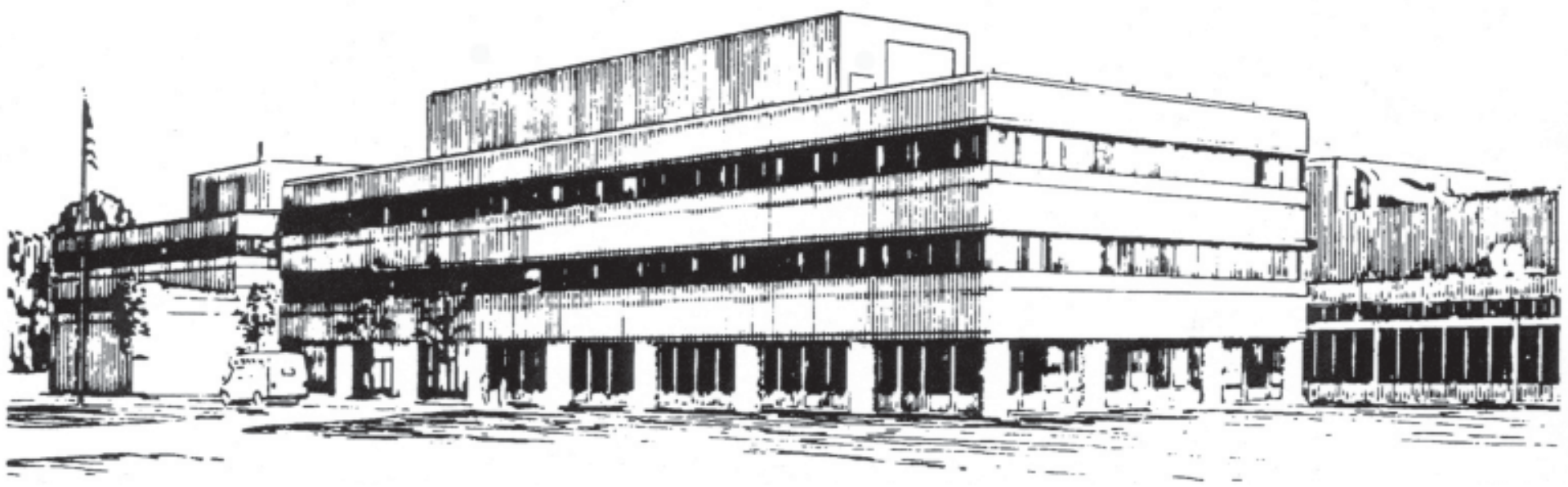

PRINCETON PLASMA PHYSICS LABORATORY PRINCETON UNIVERSITY, PRINCETON, NEW JERSEY 


\section{PPPL Reports Disclaimer}

This report was prepared as an account of work sponsored by an agency of the United States Government. Neither the United States Government nor any agency thereof, nor any of their employees, makes any warranty, express or implied, or assumes any legal liability or responsibility for the accuracy, completeness, or usefulness of any information, apparatus, product, or process disclosed, or represents that its use would not infringe privately owned rights. Reference herein to any specific commercial product, process, or service by trade name, trademark, manufacturer, or otherwise, does not necessarily constitute or imply its endorsement, recommendation, or favoring by the United States Government or any agency thereof. The views and opinions of authors expressed herein do not necessarily state or reflect those of the United States Government or any agency thereof.

\section{Availability}

This report is posted on the U.S. Department of Energy's Princeton Plasma Physics Laboratory Publications and Reports web site in Fiscal Year 2002. The home page for PPPL Reports and Publications is: http://www.pppl.gov/pub_report/

DOE and DOE Contractors can obtain copies of this report from:

U.S. Department of Energy

Office of Scientific and Technical Information

DOE Technical Information Services (DTIS)

P.O. Box 62

Oak Ridge, TN 37831

Telephone: (865) 576-8401

Fax: (865) 576-5728

Email: reports@adonis.osti.gov

This report is available to the general public from:

National Technical Information Service

U.S. Department of Commerce

5285 Port Royal Road

Springfield, VA 22161

Telephone: 1-800-553-6847 or

(703) 605-6000

Fax: (703) 321-8547

Internet: http://www.ntis.gov/ordering.htm 


\title{
Calculations of Neutral Beam Ion Confinement for the National Spherical Torus Experiment
}

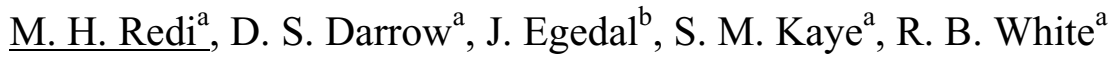 \\ ${ }^{a}$ Princeton Plasma Physics Laboratory, Princeton, NJ 08543, USA \\ ${ }^{b}$ Plasma Science and Fusion Center, MIT, Cambridge, MA 02139,USA
}

\section{Introduction}

The spherical torus (ST) concept underlies several contemporary plasma physics experiments, in which relatively low magnetic fields, high plasma edge q, and low aspect ratio combine for potentially compact, high beta and high performance fusion reactors. An important issue for the ST is the calculation of energetic ion confinement, as large Larmor radius makes conventional guiding center codes of limited usefulness and efficient plasma heating by RF and neutral beam ion technology requires minimal fast ion losses. The National Spherical Torus Experiment $\left(\mathrm{NSTX}^{1}\right)$ is a medium-sized, low aspect ratio ST, with $\mathrm{R}=0.85 \mathrm{~m}, \mathrm{a}=0.67 \mathrm{~m}, \mathrm{R} / \mathrm{a}=1.26, \mathrm{I}_{\mathrm{p}} \leq 1.4 \mathrm{MA}, \mathrm{B}_{\mathrm{t}} \leq 0.6 \mathrm{~T}, 5 \mathrm{MW}$ of neutral beam heating and 6 MW of RF heating. $80 \mathrm{keV}$ neutral beam ions at tangency radii of $0.5,0.6$ and $0.7 \mathrm{~m}$ are routinely used to achieve plasma betas above 30\%. Transport analyses for experiments on NSTX often exhibit a puzzling ion power balance ${ }^{2}$. It will be necessary to have reliable beam ion calculations to distinguish among the source and loss channels, and to explore the possibilities for new physics phenomena, such as the recently proposed compressional Alfven eigenmode ion heating.

\section{Calculations of Fast Ion Confinement}

While anomalous transport is an important consideration for thermal ion confinement, fast ion confinement appears to be classical. A beam blip experiment scanning plasma current from 0.3 to $1.0 \mathrm{MA}$ at $\mathrm{B}_{\mathrm{t}} \leq 0.35 \mathrm{~T}$ showed that measured neutron rates were in rough agreement with that expected from classical behavior ${ }^{3}$. Several methods are being used to calculate the classical transport of neutral beam ions, needed for transport analysis and perfomance planning. Initial NSTX calculations are presently limited to collisionless transport. Collisionless fast ion losses, calculated with the EIGOL ${ }^{4}, \mathrm{GYROXY}^{5}$, and CONBEAM $^{6}$ codes, have been compared for a group of NSTX plasmas, which range in $I_{p}$ from 0.6 to $1.0 \mathrm{MA}$ and $\mathrm{B}_{\mathrm{t}}$ from 0.3 to $0.45 \mathrm{~T}$ (Table 1.). EIGOL and GYROXY are full Larmor radius, Lorenz codes which compute neoclassical orbits in the $(R, Z)$ laboratory coordinates. CONBEAM provides a rapid analysis of ion guiding center topology, to which is 
added the edge Larmor radius width $\left(\rho_{\mathrm{L}}\right)$, determining an estimate of loss for specific neutral beam parameters (Fig. 1). Diamagnetic effects lead to different edge $\rho_{\mathrm{L}}$ for shots with identical values of $I_{p}$ and $B_{t}$. The beam ionization models, and thus the initial ion ensembles, are similar for the codes, which all include realistic antenna and plasma gap-to-wall geometries.

In Table 1 are given parameters for sixteen NSTX equilibria representing the range of $\mathrm{I}_{\mathrm{p}}, \mathrm{B}_{\mathrm{t}}, \mathrm{K}$ found on NSTX. CONBEAM predicts $20 \%$ to $50 \%$ losses for $80 \mathrm{keV}$ neutral beam ions for the full energy component. Not surprisingly, best confinement occurs at high $\mathrm{I}_{\mathrm{p}}, \mathrm{B}_{\mathrm{t}}$ and small $\rho_{\mathrm{L}}$. Figure 2 shows the confined fraction contours for a high current NSTX plasma, \#105572, $\mathrm{I}_{\mathrm{p}}=1.0 \mathrm{MA}, \mathrm{B}_{\mathrm{t}}=0.45$, as a function of $\mathrm{Z}$ and tangency radius. In Fig. 3 is shown the confinement fraction of $80 \mathrm{KeV}$ neutral beam ions calculated for the three beams at $0.5,0.6$ and $0.7 \mathrm{~m}$ tangency radii, as a function of $\rho_{\mathrm{L}}$ for the equilibria. Confinement improves at small $\rho_{\mathrm{L}}$ and large injection radius, with more variability at small tangency radius.

GYROXY and EIGOL have been benchmarked for identical source profiles modeling a $80 \mathrm{KeV}, 0.5 \mathrm{~m}$ tangency radius beam, in a NSTX $23 \%$ beta equilibrium. The two codes are in excellent agreement at short times: $21 \%$ loss of 54,000 ions after $7.5 \times 10^{-5} \mathrm{sec}$. GYROXY has been used to examine losses after longer orbit integration times, with $26 \%$ loss found at $7.5 \times 10^{-4} \mathrm{sec} .26 \%$ loss is also found with CONBEAM; however, the fractional loss computed by GYROXY increases linearly with time. This integration time corresponds to $1 / 20^{\text {th }}$ of an ion slowing down time; for longer integration times energy slowing down effects will be included. Although not yet parallelized, as is the parent code ORBIT, GYROXY provides detailed information about ion paths, initial and final pitches and positions as well as ion lifetimes. For the benchmark case, the final ion density is flat, with ions being preferentially lost near the magnetic axis. The ions which leave the plasma at later times are found to have more pitches near co-passing, rather than between co-passing and trapped. Convergence studies of the equilibria are important for validation and have been carried out, along with checks on the energy conservation criteria.

\section{Conclusions}

Benchmarking of EIGOL and GYROXY validate the results of both codes and are in good agreement with CONBEAM. These present calculations of collisionless beam ion losses confirmed loss of $\sim 20 \%$ for high beta on NSTX, using results from three methods of 
calculating the confinement fraction. CONBEAM provides fast estimates of confinement without details of ion orbit paths (in minutes) and predicts good confinement with high $\mathrm{I}_{\mathrm{p}}, \mathrm{B}_{\mathrm{t}}$, $1 / \rho_{\mathrm{L}}$, and high $\mathrm{R}_{\tan }$. Using EFIT analyses of NSTX equilibria, CONBEAM finds that small $\rho_{\mathrm{L}}$ at the limiter is the best guarantor of good fast ion confinement. GYROXY can provide long integration time calculations of collisionless confinement (days) and can also be used to address nonadiabatic and collisional losses. Slowing down is expected to improve fast ion confinement ${ }^{7}$. These calculations for present experiments, will support ion power balance analyses and the understanding of new phenomena on NSTX.

\section{Acknowledgement}

We are glad to acknowledge the experimental and diagnostic teams at NSTX which provided the data and basis for the analysis in this paper. Research supported by U. S. DOE Contract DE-AC02-76CH03073

[1] M. Ono, et al., Nucl. Fusion 41 (2001) 1435.

[2] E. Fredrickson, et al., Phys. Plas. 9(2002)1069. D. Gates, et al., PRL 87(2001)205003-1.

[3] W. Heidbrink, private communication (2002).

[4] D. Darrow, et al., EPS, Madeira, Portugal, 2001, paper P3.023.

[5] R. B. White, et al., Phys. Plas. 9 (2002) 1890.

[6] J. Egedal, PSFC, MIT, private communication (2002).

[7] J. Egedal, Nucl. Fus. 40 (2000) 1597. J. Egedal, IAEA Conf. alpha particles, JET (1997).

\begin{tabular}{|c|c|c|c|c|c|c|c|}
\hline Shot ID & \multicolumn{2}{|c|}{ Iр(МА) $к$} & $\mathbf{B}_{\mathbf{t}}(\mathbf{T})$ & Edge $\rho_{L}$ & $\operatorname{frac}(0.5 m)$ & $\operatorname{frac}(0.6 m)$ & $\operatorname{frac}(0.7 \mathrm{~m})$ \\
\hline $23 \%$ beta & 1.0 & 1.7 & 0.30 & 0.2309 & 0.7418 & 0.7700 & 0.7779 \\
\hline 104370 & 1.0 & 1.7 & 0.29 & 0.2333 & 0.7660 & 0.7759 & 0.7817 \\
\hline 104282 & 1.0 & 2.0 & 0.30 & 0.2806 & 0.7333 & 0.7445 & 0.7516 \\
\hline 102442 & 0.8 & 2.0 & 0.30 & 0.2927 & 0.7142 & 0.7326 & 0.7401 \\
\hline 103275 & 0.6 & 1.7 & 0.30 & 0.2794 & 0.6408 & 0.7315 & 0.7412 \\
\hline 106382 & 1.0 & 1.6 & 0.34 & 0.2098 & 0.7768 & 0.7897 & 0.7937 \\
\hline 106382(c) & 1.0 & 1.8 & 0.34 & 0.2000 & 0.7319 & 0.7375 & 0.7378 \\
\hline 104391 & 0.8 & 1.7 & 0.30 & 0.2691 & 0.7373 & 0.7489 & 0.7558 \\
\hline 104879 & 1.0 & 1.7 & 0.30 & 0.2592 & 0.7503 & 0.7600 & 0.7653 \\
\hline 105542 & 0.8 & 1.7 & 0.45 & 0.2044 & 0.7386 & 0.7806 & 0.7853 \\
\hline 105572 & 1.0 & 1.7 & 0.45 & 0.1989 & 0.7732 & 0.7873 & 0.7913 \\
\hline 105582 & 0.8 & 2.0 & 0.45 & 0.2192 & 0.7409 & 0.7739 & 0.7762 \\
\hline 105631 & 0.6 & 2.0 & 0.45 & 0.2264 & 0.6362 & 0.7611 & 0.7641 \\
\hline 105632 & 0.6 & 1.7 & 0.45 & 0.2091 & 0.6447 & 0.7685 & 0.7747 \\
\hline 105645 & 0.6 & 2.0 & 0.30 & 0.3054 & 0.4780 & 0.6833 & 0.7143 \\
\hline 105917 & 1.0 & 2.0 & 0.45 & 0.2051 & 0.7473 & 0.7823 & 0.7866 \\
\hline
\end{tabular}




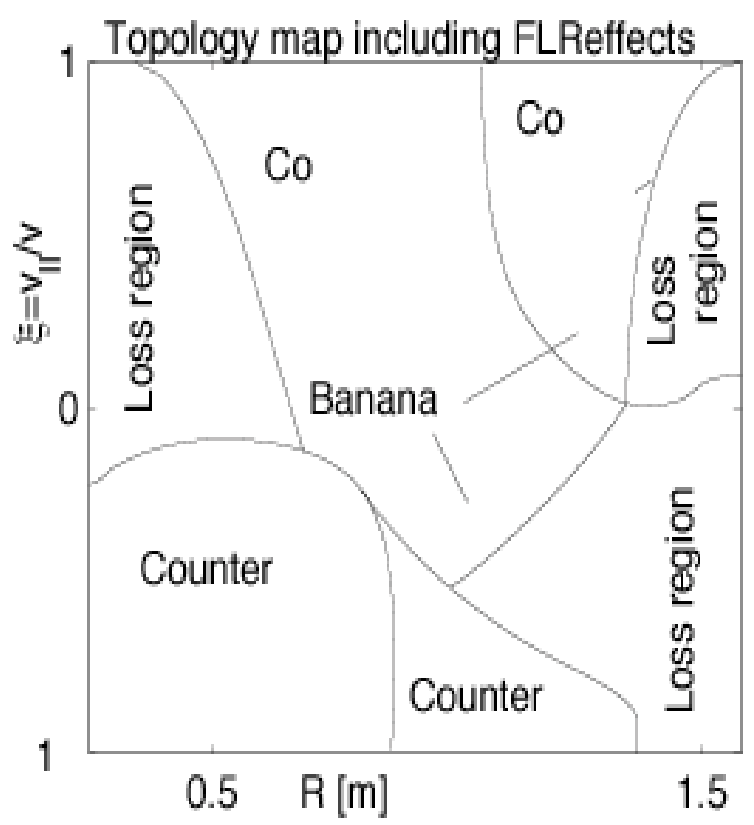

Fig. 1 lon orbit topology diagram from CONBEAM, as a function of $\xi=v / / / v$ versus $R(m)$. Loss regions occur at low and high $R$.

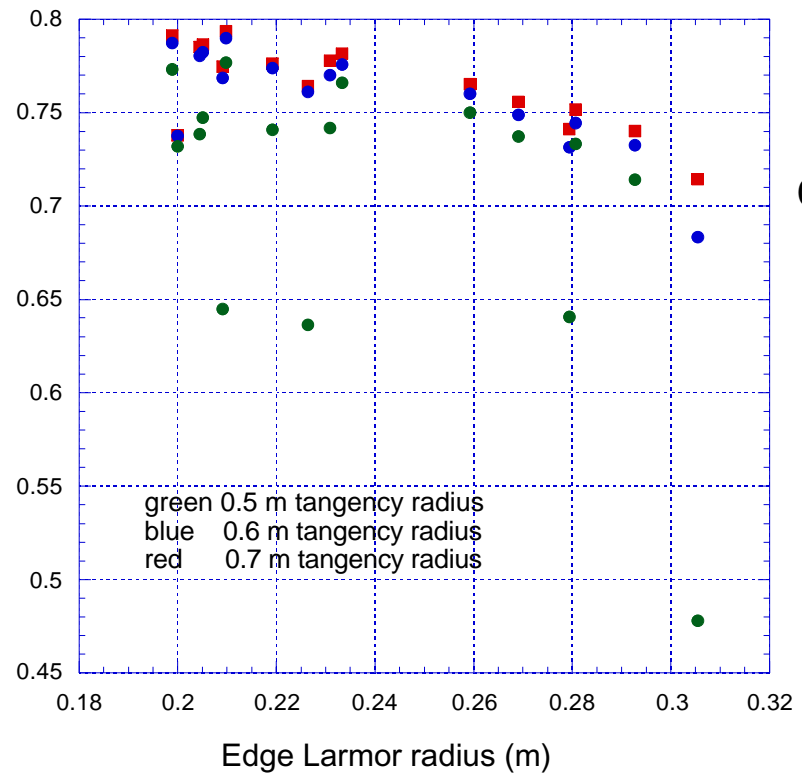

Fig. 3 Confinement fraction of 80 $\mathrm{keV}$ beam ions improves at small Larmor radius and large injection radius.

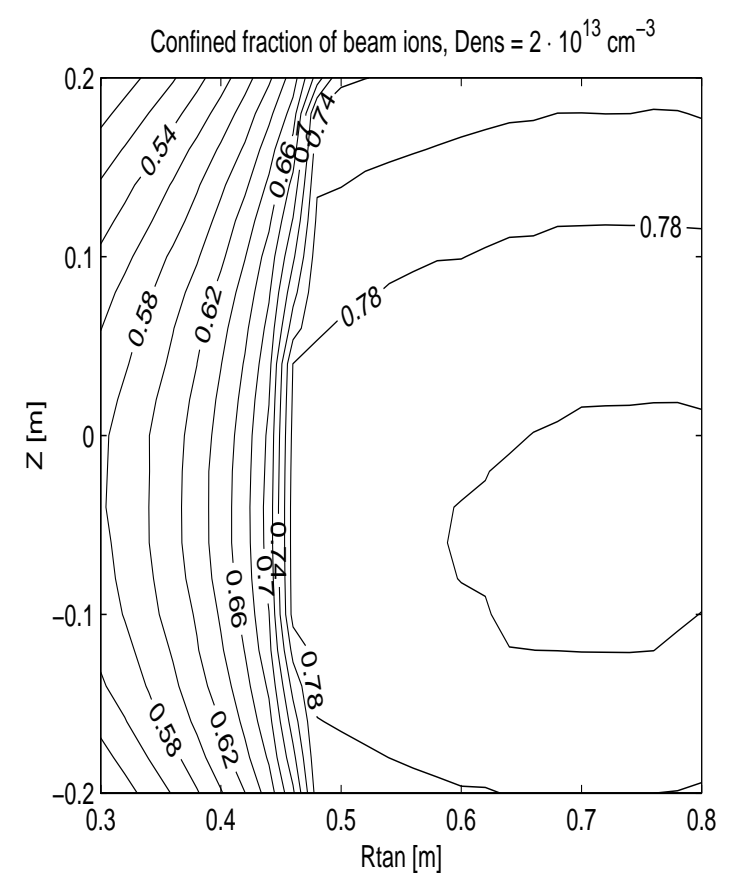

Fig. 2 Confined beam fraction of high current NSTX plasma, shot \#105572, $I p=1.0 \mathrm{MA}, B t=0.45 \mathrm{~T}$, for $Z$ versus beam tangency radius.

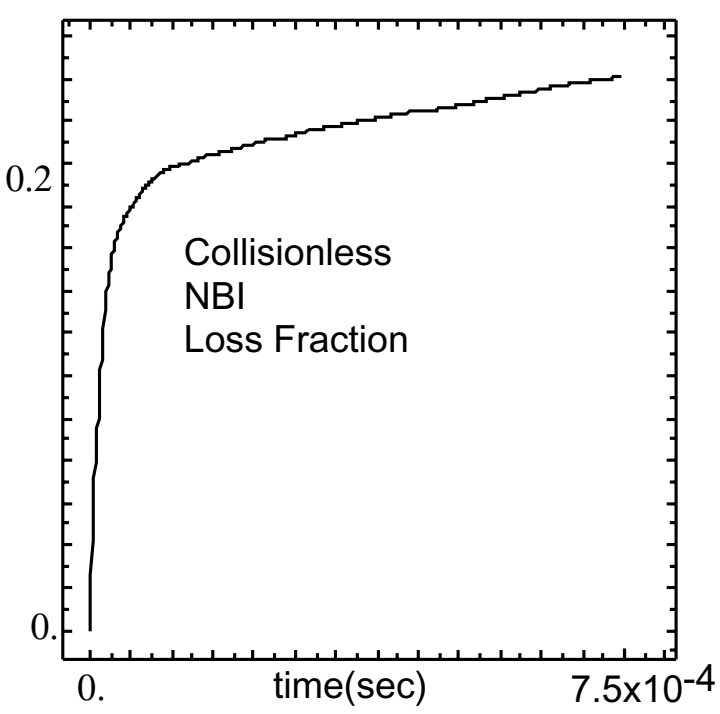

Fig. 4 GYROXY calculation of NBI loss fraction evolution over $\sim 1 / 20$ th of a slowing down time, for 54,0000 beam ions $(I \mathrm{p}=1 \mathrm{MA}, \mathrm{Bt}=0.34 \mathrm{~T}$. 


\section{External Distribution}

Plasma Research Laboratory, Australian National University, Australia

Professor I.R. J ones, Flinders University, Australia

Professor J oão Canalle, Instituto de Fisica DEQ/IF - UERJ , Brazil

Mr. Gerson O. Ludwig, Instituto Nacional de Pesquisas, Brazil

Dr. P.H. Sakanaka, Instituto Fisica, Brazil

The Librarian, Culham Laboratory, England

Library, R61, Rutherford Appleton Laboratory, England

Mrs. S.A. Hutchinson, JET Library, England

Professor M.N. Bussac, Ecole Polytechnique, France

Librarian, Max-Planck-Institut für Plasmaphysik, Germany

J olan Moldvai, Reports Library, MTA KFKI-ATKI, Hungary

Dr. P. Kaw, Institute for Plasma Research, India

Ms. P.J . Pathak, Librarian, Insitute for Plasma Research, India

Ms. Clelia De Palo, Associazione EURATOM-ENEA, I taly

Dr. G. Grosso, Instituto di Fisica del Plasma, Italy

Librarian, Naka Fusion Research Establishment, J AERI, J apan

Library, Plasma Physics Laboratory, Kyoto University, J apan

Research Information Center, National Institute for Fusion Science, J apan

Dr. O. Mitarai, Kyushu Tokai University, J apan

Library, Academia Sinica, Institute of Plasma Physics, People's Republic of China

Shih-Tung Tsai, Institute of Physics, Chinese Academy of Sciences, People's Republic of China

Dr. S. Mirnov, TRINITI, Troitsk, Russian Federation, Russia

Dr. V.S. Strelkov, Kurchatov Institute, Russian Federation, Russia

Professor Peter Lukac, Katedra Fyziky Plazmy MFF UK, Mlynska dolina F-2, Komenskeho Univerzita, SK-842 15 Bratislava, Slovakia

Dr. G.S. Lee, Korea Basic Science Institute, South Korea

Mr. Dennis Bruggink, Fusion Library, University of Wisconsin, USA

Institute for Plasma Research, University of Maryland, USA

Librarian, Fusion Energy Division, Oak Ridge National Laboratory, USA

Librarian, Institute of Fusion Studies, University of Texas, USA

Librarian, Magnetic Fusion Program, Lawrence Livermore National Laboratory, USA

Library, General Atomics, USA

Plasma Physics Group, Fusion Energy Research Program, University of California at San Diego, USA

Plasma Physics Library, Columbia University, USA

Alkesh Punjabi, Center for Fusion Research and Training, Hampton University, USA

Dr. W.M. Stacey, Fusion Research Center, Georgia Institute of Technology, USA

Dr. J ohn Willis, U.S. Department of Energy, Office of Fusion Energy Sciences, USA

Mr. Paul H. Wright, Indianapolis, Indiana, USA 
The Princeton Plasma Physics Laboratory is operated by Princeton University under contract with the U.S. Department of Energy.

\author{
Information Services \\ Princeton Plasma Physics Laboratory \\ P.O. Box 451 \\ Princeton, NJ 08543
}

Phone: 609-243-2750

Fax: 609-243-2751

e-mail: pppl_info@pppl.gov

Internet Address: http://www.pppl.gov 